\title{
Article \\ The Effects of Chemical Oxidation and High-Temperature Reduction on Surface Functional Groups and the Adsorption Performance of Biochar for Sulfamethoxazole Adsorption
}

\author{
Jifei Hou ${ }^{1,2,+}$, Jialin Yu ${ }^{1,+}$, Wenxuan $\mathrm{Li}^{1}$, Xiudan $\mathrm{He}^{1}$ and Xuede Li ${ }^{1,2, *}$ \\ 1 School of Resources and Environment, Anhui Agricultural University, Hefei 230036, China; \\ houjf90@ahau.edu.cn (J.H.); yj109160101@163.com (J.Y.); 112210036@163.com (W.L.); \\ serendipity0903@126.com (X.H.) \\ 2 Hefei Scientific Observing and Experimental Station of Agro-Environment, \\ Ministry of Agriculture and Rural Affairs, Hefei 230036, China \\ * Correspondence: xuedel@ahau.edu.cn \\ + These authors contributed equally to this work.
}

check for updates

Citation: Hou, J.; Yu, J.; Li, W.; He, X.; $\mathrm{Li}, \mathrm{X}$. The Effects of Chemical Oxidation and High-Temperature Reduction on Surface Functional Groups and the Adsorption Performance of Biochar for Sulfamethoxazole Adsorption. Agronomy 2022, 12, 510. https:// doi.org/10.3390/agronomy12020510

Academic Editor: David Houben

Received: 17 January 2022

Accepted: 11 February 2022

Published: 18 February 2022

Publisher's Note: MDPI stays neutral with regard to jurisdictional claims in published maps and institutional affiliations.

Copyright: (C) 2022 by the authors. Licensee MDPI, Basel, Switzerland. This article is an open access article distributed under the terms and conditions of the Creative Commons Attribution (CC BY) license (https:// creativecommons.org/licenses/by/ $4.0 /)$.

\begin{abstract}
Biochar is a beneficial adsorbent for the treatment of organic pollutants in the environment. The association of oxygen functional groups and adsorption behaviors has not been well investigated. In this paper, the oxidation-modified biochar (O-BC) and the reduction-modified biochar (R-BCX) were prepared by $\mathrm{Co}^{2+}$ / peroxymonosulfate chemical oxidation and high-temperature reduction, respectively. The modified biochars were used to remove sulfamethoxazole (SMX) from water, and the adsorption amounts of biochar followed the order of R-BC700 $\left(14.66 \mathrm{mg} \cdot \mathrm{L}^{-1}\right)>\mathrm{O}-\mathrm{BC}\left(4.91 \mathrm{mg} \cdot \mathrm{L}^{-1}\right)$ $>\mathrm{BC}\left(0.16 \mathrm{mg} \cdot \mathrm{L}^{-1}\right)$. Additionally, the effects of water chemical conditions (i.e., ionic strength, solution $\mathrm{pH}$ and humic acid (HA) concentration) on the adsorption of SMX on biochar, were further investigated. Combining physical adsorption, $\mathrm{X}$-ray electron spectroscopy, and zeta potentiometer characterization techniques, the effect of functional groups on the adsorption mechanism was further explored, revealing the importance of various oxygen functional groups for SMX adsorption. The results showed that $\mathrm{C}=\mathrm{O}$ and $\mathrm{C}=\mathrm{C}$, resulting in $\pi-\pi$ interaction, were in favor of the adsorption of SMX, while C-O was not conducive to the adsorption of SMX, due to the steric hindrance and the negative surface charge. Additionally, the hydrophobic effect of the biochar was also one of the adsorption mechanisms.
\end{abstract}

Keywords: oxidized biochar; reduced biochar; oxygen functional groups; adsorption; sulfamethoxazole

\section{Introduction}

In recent decades, the use of emerging micro-pollutants, such as drugs and personal care products, has increased, which has become a concern for sewage and wastewater treatment plants. Particularly, antibiotics and their metabolites are frequently detected at a trace level $\left(\mu \mathrm{g} \cdot \mathrm{L}^{-1}\right)$ in surface water bodies [1]. Due to their widespread use, antibiotics have been constantly released into the environment, and are classified as emerging pseudo-persistent pollutants. The bioaccumulation of antibiotics in aquatic organisms will accumulate along the biological chain, which could induce resistance genes in animals or microorganisms. The production of resistance genes could enhance the resistance of pathogenic antibiotics, resulting in a serious threat to ecological health [2,3]. Among the used antibiotics, sulfamethoxazole (SMX) is one of the most detected antibiotics in water bodies. The concentration of SMX in surface water could reach 14.8-297 ng. $\mathrm{L}^{-1}$ [4]. Due to the high stability and long half-life (85-100 days) of SMX, it poses a serious threat to human health.

The common treatment processes for antibiotics in water bodies included advanced oxidation, photolysis and adsorption [5]. Among them, the adsorption method is considered an effective treatment technology for the removal of organic micro-pollutants [6]. 
Thus, traditional and emerging adsorbents, e.g., biochar and carbon nanotubes, have been extensively investigated [7]. Among them, biochar has a good pore structure and abundant surface functional groups, presenting a good adsorption capacity for a variety of organic substances, such as antibiotics, pesticides and dyes [8]. Studies have shown that the removal mechanisms of carbon materials for SMX mainly include hydrophobic interactions, electrostatic interactions, $\pi-\pi$ electron donor-acceptor ( $\pi-\pi \mathrm{EDA})$ interactions, hydrogen bonds (H-bond), etc., which are closely related to the special surface area and surface functional groups of carbon materials [9]. Greiner et al. [10] pyrolyzed pine wood to prepare biochar for SMX adsorption. After heating the biochar in an oxygen-rich environment, the adsorption capacity of SMX was 3.5 fold higher than that of the fresh biochar, indicating the importance of oxygen functional groups. Teixidó et al. [11] found that $\pi-\pi$ EDA interactions and charge-assisted H-bond controls sulfamethazine sorption on hardwood biochars, while Wu et al. [12] suggested that electrostatic repulsion played an important role in SMX sorption by sediment chars. These different sorption mechanisms are probably attributed to the various oxygen functional groups of biochars. Commonly, hydroxyl (-OH), and carbonyl (-CO) on the surface of biochar were considered as important surface groups of carbon materials [13]. However, the effects of the various oxygen functional groups on the adsorption capacity of biochar for SMX are not clear. The treatments of chemical oxidation with oxidizing agents (e.g., $\mathrm{HNO}_{3}, \mathrm{H}_{2} \mathrm{SO}_{4}, \mathrm{H}_{2} \mathrm{O}_{2}$ ) and high-temperature reduction in an inert atmosphere (e.g., $\mathrm{N}_{2}, \mathrm{He}$ ), were the common methods used to modify the surface of biochar with different oxygen functional groups $[14,15]$. Peroxymonosulfate (PMS) as a solid oxidizer was safer than $\mathrm{HNO}_{3}$ and $\mathrm{H}_{2} \mathrm{O}_{2}$, and could be activated by the generation of reactive oxygen species (ROS, e.g., ${ }^{\circ} \mathrm{OH}, \mathrm{SO}_{4}-{ }^{1} \mathrm{O}_{2}$ ) by biochar [16]. During the activation process, the content of $\mathrm{C}-\mathrm{O} / \mathrm{C}-\mathrm{OH}$ and $\mathrm{C}=\mathrm{O}$ increased on the surface of biochar [17]. Additionally, the $\mathrm{Co}^{2+}$ ion, as the homogenous catalyst with the highest PMS catalytic activity, could efficiently activate PMS to generate ROS, thus oxidizing carbon materials to generate surface acidic functional groups [18]. Furthermore, heating under an inert atmosphere with different temperatures could selectively remove some of the oxygen functional groups. For example, the decomposition temperatures of phenolic hydroxyl groups and carbonyl were $873 \mathrm{~K}$ and $1253 \mathrm{~K}$, respectively [19].

Hence, in this study, $\mathrm{Co}^{2+} / \mathrm{PMS}$ oxidation and high-temperature reduction were selected to modify surface oxygen functional groups on biochars. The adsorption capacity of oxidation- and reduction-modified biochars on SMX was investigated, and the adsorption performance of modified biochars on SMX was evaluated via adsorption isotherm models and kinetic models. Additionally, the effect of water chemical conditions, i.e., ionic strength, solution $\mathrm{pH}$ and humic acid (HA) concentration, on the adsorption of SMX on biochar, was further investigated. By combining physical adsorption, X-ray electron spectroscopy and zeta potentiometer characterization techniques, the effect of functional groups on the adsorption mechanism was explored. Research on the effect of various oxygen functional groups on the adsorption capacity of biochar is significant for revealing the adsorption mechanism of carbon materials from different environments. In particular, this research could be conducive to explaining the transportation of organic matter adsorbed on biochar in the environment.

\section{Materials and Methods}

\subsection{Materials}

All chemicals used in this experiment were analytical grade without further purification. Deionized (DI) water was produced from the Milli-Q water purification system $\left(18.2 \mathrm{M} \Omega \cdot \mathrm{cm}^{-1}\right)$. Wheat straw biomass charcoal with a calcination temperature of $400{ }^{\circ} \mathrm{C}$ was purchased from Anhui Diyuan Modern Agricultural Investment Development Co., Ltd (Anhui Chuzhou, China). 


\subsection{Preparation of Adsorbents}

A total of $1.0 \mathrm{~g}$ of wheat straw biomass charcoal (BC) was ground and sieved (200 mesh), and added to $200 \mathrm{~mL}$ of deionized water. The mixture was placed in a $60^{\circ} \mathrm{C}$ water bath and continuously stirred. Then, $10.0 \mathrm{~g}$ of PMS and $2.0 \mathrm{~g}$ of $\mathrm{Co}\left(\mathrm{NO}_{3}\right)_{2} \cdot 6 \mathrm{H}_{2} \mathrm{O}$ were added into the $\mathrm{BC}$ solution, reacting for $8 \mathrm{~h}$ under the $60^{\circ} \mathrm{C}$ water bath conditions. After the reaction, the carbon materials were washed with deionized water to neutrality, and dried at $60{ }^{\circ} \mathrm{C}$ for $12 \mathrm{~h}$. The obtained materials were labeled as oxide-modified biochar $(\mathrm{O}-\mathrm{BC})$.

The $\mathrm{O}-\mathrm{BC}$ was placed in a tube furnace in a pure nitrogen atmosphere and reacted at a predetermined temperature $\left(600^{\circ} \mathrm{C}, 700{ }^{\circ} \mathrm{C}\right.$ and $\left.800{ }^{\circ} \mathrm{C}\right)$ for $4 \mathrm{~h}$ with a heating rate of $5^{\circ} \mathrm{C} \cdot \mathrm{min}^{-1}$. After reaching room temperature, the obtained biochar was marked as R-BCX, where $\mathrm{X}$ signifies reduction temperature.

\subsection{Characterization of Adsorbents}

An X-ray diffractometer (D8 ADVANCE X-ray diffractometer, Bruker, Germany) was used to analyze the mineral crystal and structure of the adsorbents. The structure defects of biochar were determined by Raman spectroscopy (Renishaw inVia, Renishaw, England). $\mathrm{N}_{2}$ physical adsorption (ASAP 2460, Micromeritics, USA) was used to analyze the specific surface area and pore volume of the adsorbents. The zeta potential of biochar was measured by a zeta potential meter (DelsaMaxPRO, Beckman Coulter, Brea, CA, USA). The surface compositions and chemical states of biochar were analyzed by an X-ray electron spectrometer (ESCALAB 250 X-ray photoelectron spectrometer, Thermo Fisher Scientific, Waltham, MA, USA). The $\mathrm{C}$ and $\mathrm{H}$ contents of the biochars were analyzed by an elemental analyzer (Vario Micro Cube, Elementar, Germany). The hydrophilia of the biochars was detected on the contact angle meter (JY-82C, Hebei Chengde Dingsheng Co. Ltd., China) at room temperature with a water droplet of $16.0 \mu \mathrm{L}$.

\subsection{Adsorption Experiments}

The adsorption isotherm experiment was obtained via a batch adsorption experiment. A total of $10 \mathrm{mg}$ of adsorbents were added into a $40 \mathrm{~mL}$ EPA bottle containing $20 \mathrm{~mL}$ of SMX with different concentrations $\left(0.5-30 \mathrm{mg} \cdot \mathrm{L}^{-1}\right)$. Then the bottle was shaken at $25^{\circ} \mathrm{C}$ for $24 \mathrm{~h}$ to reach adsorption equilibrium. The concentration of SMX was determined by high-performance liquid chromatography. The liquid phase test conditions of SMX were as follows: mobile phase $0.5 \%$ formic acid: acetonitrile $(\mathrm{V}: \mathrm{V}=40: 60)$, column temperature $40{ }^{\circ} \mathrm{C}$, flow rate $1.0 \mathrm{~mL} \cdot \mathrm{min}^{-1}$, injection volume $20 \mu \mathrm{L}$, and UV wavelength $270 \mathrm{~nm}$. The adsorption capacity of SMX was calculated using Formula (1). Additionally, the Langmuir model and the Freundlich model were used to fit the adsorption process.

$$
q_{\mathrm{e}}=\left(\left(C_{0}-C_{\mathrm{e}}\right) \times \mathrm{V}\right) / \mathrm{m}
$$

where $q_{\mathrm{e}}\left(\mathrm{mg} \cdot \mathrm{g}^{-1}\right)$ is the equilibrium adsorption capacity of SMX on biochar under the initial SMX concentration $C_{0}\left(\mathrm{mg} \cdot \mathrm{L}^{-1}\right), C_{\mathrm{e}}\left(\mathrm{mg} \cdot \mathrm{L}^{-1}\right)$ is the equilibrium concentration of $\mathrm{SMX}$, and $\mathrm{m}(\mathrm{g})$ is the dosage of the adsorbent.

Adsorption kinetics were conducted in an Erlenmeyer flask with $200 \mathrm{~mL}$ of $15 \mathrm{mg} \cdot \mathrm{L}^{-1}$ SMX. A quantity of $0.1 \mathrm{~g}$ of adsorbent was added to the solution, then samples were taken at preset time intervals. Single-point adsorption experiments with three parallels were conducted to investigate the effect of $\mathrm{pH}$, ion species/strength, and HA on the adsorption of SMX. A quantity of $10 \mathrm{mg}$ of adsorbents was added to an EPA bottle containing $20 \mathrm{~mL}$ of $15 \mathrm{mg} \cdot \mathrm{L}^{-1} \mathrm{SMX}$ solution. For the ion species/strength experiment, $\mathrm{NaCl}, \mathrm{CaCl}_{2}, \mathrm{NaNO}_{3}$, and $\mathrm{Na}_{2} \mathrm{SO}_{4}$ were used as ion sources with concentrations from $0.001 \mathrm{M}$ to $0.2 \mathrm{M}$. The effect of HA on SMX adsorption was conducted with a concentration of HA from 0 to $80 \mathrm{mg} \cdot \mathrm{L}^{-1}$. In the $\mathrm{pH}$ influence experiment, $0.1 \mathrm{M} \mathrm{NaOH}$ and $\mathrm{HCl}$ were used to adjust the solution $\mathrm{pH}$ from 3 to 11. The other steps were the same as the adsorption isotherm experiment. 


\section{Results}

\subsection{Characterization of Adsorbents}

The XRD patterns of the adsorbents are shown in Figure 1a. All samples presented two diffraction peaks at $20.8^{\circ}$ and $26.6^{\circ}$, corresponding to amorphous carbon (002) and $\mathrm{SiO}_{2}$ (101), respectively [20]. Additionally, the XRD patterns of BC showed diffraction peaks of $\mathrm{KCl}(200,220,222)$ at $28.3^{\circ}, 40.5^{\circ}$ and $50.1^{\circ}$, and $\mathrm{CaCO}_{3}(104)$ at $29.4^{\circ}$ [21]. After modification, the diffraction peaks of $\mathrm{KCl}$ and $\mathrm{CaCO}_{3}$ were absent from $\mathrm{O}-\mathrm{BC}$ and $\mathrm{R}-\mathrm{BCX}$, which was ascribed to the elution of $\mathrm{CaCO}_{3}$ and $\mathrm{KCl}$ from the biochar during the oxidative modification process [22].
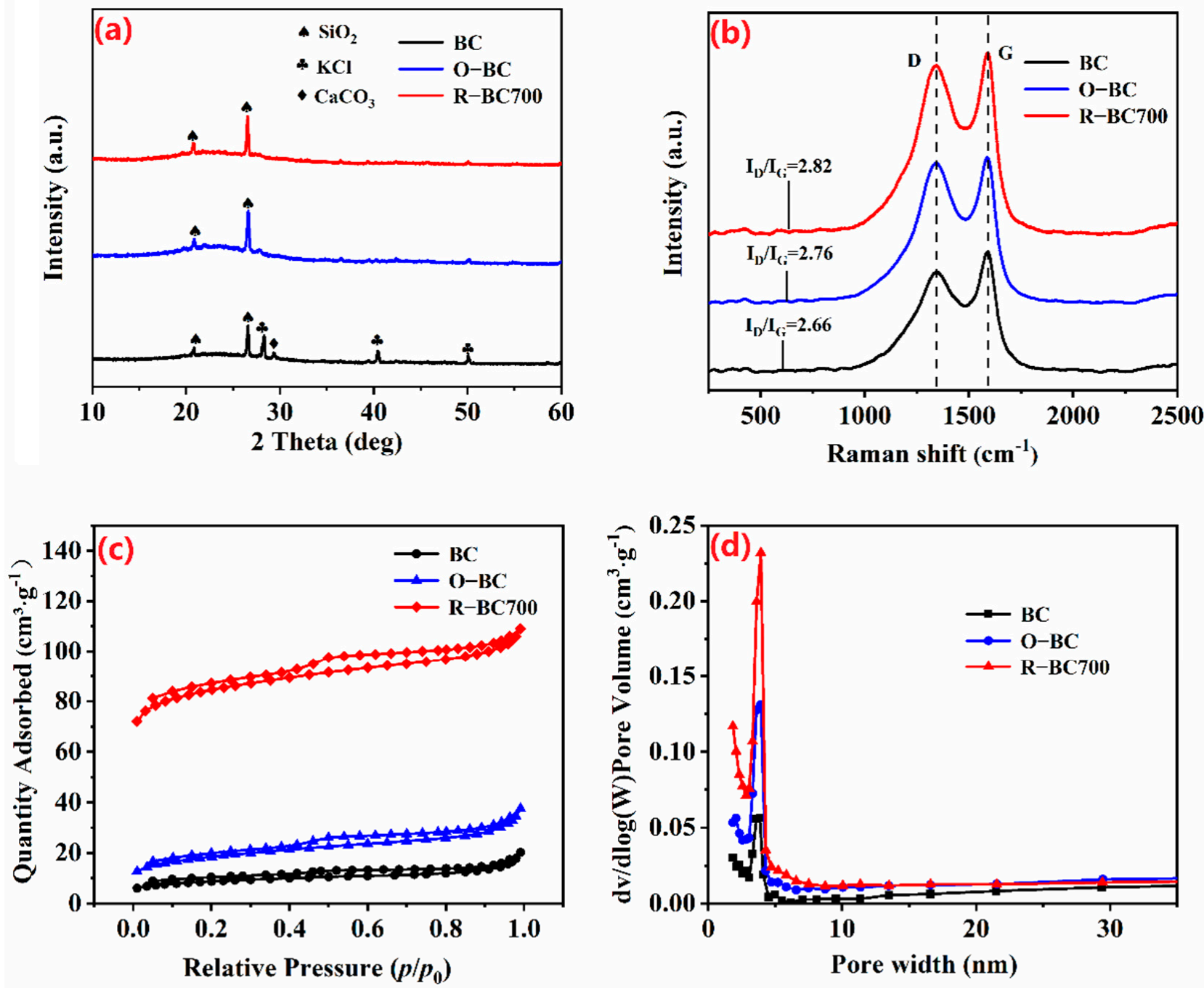

Figure 1. (a) Wide-angle XRD patterns, (b) Raman spectra, (c) $\mathrm{N}_{2}$ adsorption-desorption isotherms, and (d) pore size distributions of biochars.

To investigate the variation of carbon structure, the Raman spectra of $\mathrm{BC}, \mathrm{O}-\mathrm{BC}$, and $\mathrm{R}$ BC700 are presented in Figure 1b. Two distinct characteristic peaks appeared at $1350 \mathrm{~cm}^{-1}$ and $1581 \mathrm{~cm}^{-1}$, corresponding to the $\mathrm{D}$ band and $\mathrm{G}$ band, respectively, which reflected the structural defects of biochar and the degree of graphitization [23]. The $I_{\mathrm{D}} / I_{\mathrm{G}}$ of O-BC was 2.76, higher than that of $\mathrm{BC}$ (2.66), which was obtained by peak area integration. After high-temperature carbonization, the $I_{\mathrm{D}} / I_{\mathrm{G}}$ of R-BC700 further increased to 2.82, indicating that both oxidation and high-temperature reduction would generate defects in biochar [24].

The specific surface area and pore structure of BC, O-BC and R-BC700 are shown in Figure $1 c, d$. According to the IUPAC classification, the $\mathrm{N}_{2}$ adsorption analysis curves of the biochars were classified as type IV with the formation of $\mathrm{H}_{3}$ hysteresis loops, indicative 
of the tubular mesoporous structure of the biochars [25]. The pore distributions of $\mathrm{BC}$, $\mathrm{O}-\mathrm{BC}$ and $\mathrm{R}-\mathrm{BC} 700$ were very narrow, and the most probable pore diameters were $3.95 \mathrm{~nm}$, calculated by the $\mathrm{BJH}$ method using the desorption branch, which suggested that oxidation and reduction modification played a minor role in the pore size of the biochars. The surface area and pore structure parameters of biochar are listed in Table 1. Compared with $\mathrm{BC}$, the specific surface area and pore volume of $\mathrm{O}-\mathrm{BC}$ and $\mathrm{R}-\mathrm{BC} 700$ both increased. The specific surface area of $\mathrm{O}-\mathrm{BC}$ only increased to $65 \mathrm{~m}^{2} \cdot \mathrm{g}^{-1}$, ascribed to the elution of minerals and soluble organic matter from $\mathrm{BC}$ during the oxidation modification process, which was similar to the XRD results. The specific surface area and micropore volume of R-BC700 significantly increased to 4.5 and 9.6 times that of $\mathrm{O}-\mathrm{BC}$, respectively. The results were ascribed to the fact that high-temperature modification could destroy carbon structure and increase pore volume in an inert atmosphere. Additionally, the micropore content of R-BC700 increased from $16.12 \%$ to $57.14 \%$, indicative of a benefit for the formation of micropores at high-temperature carbonization [26].

Table 1. Pore structural parameters of biochars.

\begin{tabular}{|c|c|c|c|c|c|}
\hline \multirow[b]{2}{*}{ Biochars } & \multirow{2}{*}{$\begin{array}{l}\text { BET Surface Area } \\
\left(S_{\text {BET }}{ }^{a}, \mathrm{~m}^{2} \cdot \mathrm{g}^{-1}\right)\end{array}$} & \multicolumn{3}{|c|}{ Pore Volume } & \multirow{2}{*}{$\begin{array}{l}\text { Average Pore Width } \\
\qquad\left(L_{0}, \mathrm{~nm}\right)\end{array}$} \\
\hline & & $\begin{array}{c}\text { Total Pore } \\
\left(V_{\mathrm{t}}^{\mathrm{b}}, \mathrm{cm}^{3} \cdot \mathrm{g}^{-1}\right)\end{array}$ & $\begin{array}{c}\text { Micropore } \\
\left(V_{\text {micro }}{ }^{c}, \mathrm{~cm}^{3} \cdot \mathrm{g}^{-1}\right)\end{array}$ & $\begin{array}{l}\text { Micropore } \\
\left(V_{\text {Mic }} \%\right)\end{array}$ & \\
\hline $\mathrm{BC}$ & 31 & 0.031 & 0.005 & 16.12 & 3.96 \\
\hline $\mathrm{O}-\mathrm{BC}$ & 65 & 0.058 & 0.010 & 17.24 & 3.52 \\
\hline R-BC700 & 294 & 0.168 & 0.096 & 57.14 & 2.29 \\
\hline
\end{tabular}

The elemental analysis results of the adsorbents are shown in Table 2. The lower value of $\mathrm{H} / \mathrm{C}$ indicates the higher the aromaticity of the carbon materials [27]. The $\mathrm{H} / \mathrm{C}$ of the O-BC adsorbent was 0.030 , which is slightly higher than the H/C of BC (0.029). This might be due to the addition of oxygen functional groups on the carbon surface during the oxidation modification process, especially the addition of the carboxyl functional groups. The $\mathrm{H} / \mathrm{C}$ of $\mathrm{R}-\mathrm{BCX}$ adsorbents was significantly affected by the calcination temperature. The H/C ratios of R-BC600, R-BC700 and R-BC800 were 0.012, 0.014 and 0.003, respectively, which were much lower than that of $\mathrm{O}-\mathrm{BC}$. The phenomenon was ascribed to the dehydration and decarboxylation of biochar during the high-temperature carbonization process [28]. XPS analysis also shows similar results, displayed in Table 2. The content of C and $\mathrm{O}$ elements varied during oxidation and high-temperature reduction, indicating that oxidation and high-temperature reduction could significantly affect the functional groups of carbon materials.

Table 2. Elemental composition of biochars.

\begin{tabular}{cccccc}
\hline \multirow{2}{*}{ Biochars } & \multicolumn{3}{c}{ Elemental Analysis (\%) } & \multicolumn{2}{c}{ XPS (Atomic\%) } \\
\cline { 2 - 6 } & C & H & H/C & C & O \\
\hline BC & 52.35 & 1.53 & 0.029 & 85.10 & 14.90 \\
O-BC & 57.70 & 1.76 & 0.030 & 79.33 & 20.67 \\
R-BC600 & 62.87 & 0.77 & 0.012 & 87.07 & 12.93 \\
R-BC700 & 61.40 & 0.86 & 0.014 & 87.30 & 12.70 \\
R-BC800 & 61.75 & 0.20 & 0.003 & 87.43 & 12.57 \\
\hline
\end{tabular}

To further investigate the variation of the functional groups of $\mathrm{BC}, \mathrm{O}-\mathrm{BC}$ and $\mathrm{R}-$ $\mathrm{BCX}, \mathrm{C} 1 \mathrm{~s}$ and $\mathrm{O} 1 \mathrm{~s}$ spectra were fitted, and the result is shown in Figure 2. As shown in Figure $2 \mathrm{~b}-\mathrm{f}$, the $\mathrm{C} 1 \mathrm{~s}$ peaks were fitted to three peaks, i.e., $\mathrm{C}-\mathrm{C} / \mathrm{C}=\mathrm{C}(284.70 \mathrm{eV}-284.77 \mathrm{eV})$, $\mathrm{C}-\mathrm{O}(285.30 \mathrm{eV}-285.90 \mathrm{eV})$ and $\mathrm{C}=\mathrm{O}(287.90 \mathrm{eV}-289.00 \mathrm{eV})$. After oxidation modification, the content of $\mathrm{C}=\mathrm{O}$ increased from $3.5 \%(\mathrm{BC})$ to $6.0 \%$ (O-BC), possibly ascribed to the 
oxidation of the defect edges of biochar [17]. Conversely, for $\mathrm{R}-\mathrm{BCX}$, the ratio of $\mathrm{C}=\mathrm{C}$ significantly increased with the increase of the carbonization temperature from $600{ }^{\circ} \mathrm{C}$ to $800^{\circ} \mathrm{C}$, indicative of the enhancement of the formation of aromatic structures in an inert high-temperature condition. On the other hand, the content of C-O on R-BCX gradually decreased from $24.5 \%$ to $16.6 \%$ with the temperature increase from $600{ }^{\circ} \mathrm{C}$ to $800{ }^{\circ} \mathrm{C}$, due to the decomposition of $\mathrm{C}-\mathrm{OH}$ at a high calcination temperature [19]. In contrast, the content of $\mathrm{C}=\mathrm{O}$ on $\mathrm{R}-\mathrm{BCX}$ increased, which was higher than $\mathrm{O}-\mathrm{BC}$, indicative of the greater stability of $\mathrm{C}=\mathrm{O}$ than $\mathrm{C}-\mathrm{O}$ at high temperatures [29]. The O1s peaks of biochars were also fitted with two peaks, i.e., $\mathrm{C}-\mathrm{O}(531.6-532.3 \mathrm{eV})$ and $\mathrm{C}=\mathrm{O}(533.1-533.3 \mathrm{eV})$, and the deconvolution results are shown in Figure $2 \mathrm{~g}-\mathrm{k}$. The variation of $\mathrm{C}-\mathrm{O}$ and $\mathrm{C}=\mathrm{O}$ on $\mathrm{BC}, \mathrm{O}-\mathrm{BC}$ and $\mathrm{R}-\mathrm{BCX}$ was in line with the deconvolution results of $\mathrm{C} 1 \mathrm{~s}$.
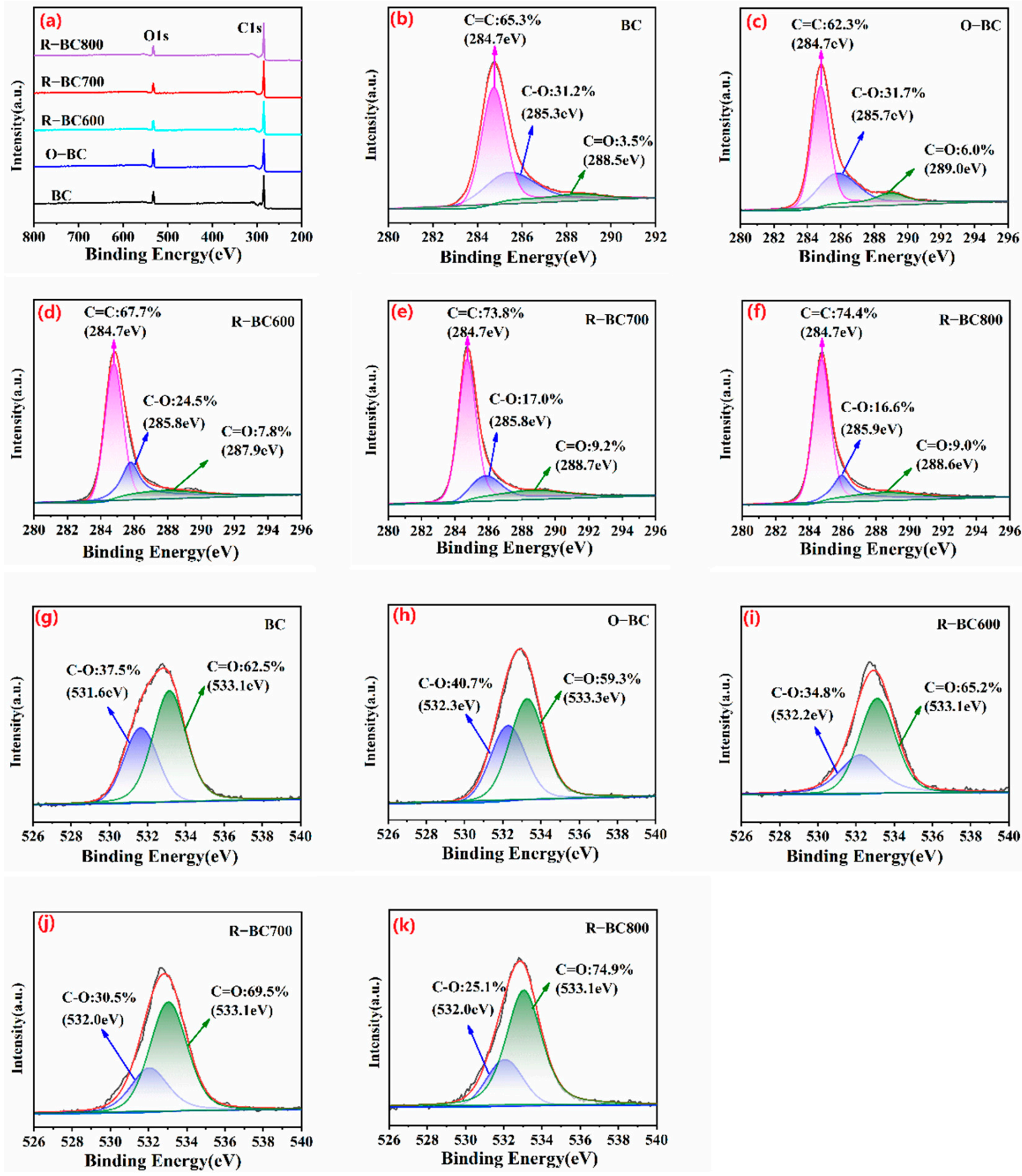

Figure 2. (a) XPS spectra, and the deconvolutions of $(\mathbf{b}, \mathbf{g})$ the full $\mathrm{C}$ 1s and $\mathrm{O}$ 1s of $\mathrm{BC},(\mathbf{c}, \mathbf{h}) \mathrm{O}-\mathrm{BC}$, (d,i) R-BC600, (e,j) R-BC700 and (f,k) R-BC800. 
To detect the influence of oxygen functional groups on the hydrophilic and hydrophobic materials, the contact angles of $\mathrm{BC}, \mathrm{O}-\mathrm{BC}$ and $\mathrm{R}-\mathrm{BC} 700$ are presented in Figure 3. All samples presented a small contact angle with $\theta<60^{\circ}$, ascribed to the high content of oxygen (Table 2) [30]. Compared to BC $\left(22.71^{\circ}\right)$ and R-BC700 $\left(27.49^{\circ}\right)$, the contact angle of O-BC performing the smallest was $18.42^{\circ}$, indicative of the best hydrophilicity of O-BC. [31]. The hydrophilicity of O-BC could be attributed to the abundant formation of $\mathrm{C}-\mathrm{O}$ and $\mathrm{C}=\mathrm{O}$ functional groups via activated PMS oxidating the surface of $\mathrm{BC}$. Inversely, the weak hydrophilicity of R-BC700 could be ascribed to the decomposition of oxygen functional groups during the calcination process under an $\mathrm{N}_{2}$ atmosphere [32].

(a) (b)

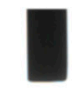

(c)

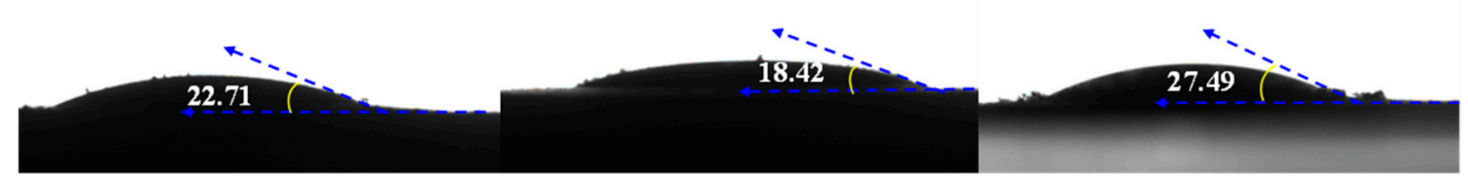

Figure 3. Contact angles of (a) BC, (b) O-BC and (c) R-BC700.

\subsection{Adsorption Isotherms and Adsorption Kinetics}

The adsorption isotherms of adsorbents to SMX are shown in Figure 4a. With the increase of SMX initial concentration, the adsorption capacity of biochar for SMX showed an increasing trend, and then slowly approached equilibrium. The adsorption capacities of O-BC and R-BCX were significantly higher than that of $B C\left(0.16 \mathrm{mg} \cdot \mathrm{g}^{-1}\right)$, and the adsorption capacities followed the order of R-BC700 > R-BC800 > R-BC600 > O-BC > BC. The adsorption capacity of O-BC to SMX was $4.91 \mathrm{mg} \cdot \mathrm{g}^{-1}$, which might be due to the increase of $\mathrm{C}=\mathrm{O}$ content from $3.5 \%$ before modification to $6.0 \%$ afterwards. The electronrich group $\mathrm{C}=\mathrm{O}$ with lone pair electrons could be an electron donor, enhancing the $\pi-\pi$ interaction between SMX and O-BC. The adsorption capacity of R-BCX was significantly higher than that of $\mathrm{O}-\mathrm{BC}$. This might be ascribed to the removal of $\mathrm{C}-\mathrm{O}$ functional groups on the surface of biochar, causing reduced steric hindrance and the increased contact of $\mathrm{SMX}$ with the adsorption sites [33]. Moreover, the content of electron-donating $\mathrm{C}=\mathrm{C}$ and $\mathrm{C}=\mathrm{O}$ bonds on $\mathrm{R}-\mathrm{BCX}$ significantly increased, which was beneficial for enhancing the adsorption of SMX by $\pi-\pi$ interaction. It is noteworthy that the adsorption capacity of SMX on R-BCX increased and then decreased with the temperature increase from $600{ }^{\circ} \mathrm{C}$ to $800^{\circ} \mathrm{C}$. Among them, R-BC700 showed the best adsorption capacity of SMX. At an initial concentration of $30 \mathrm{mg} \cdot \mathrm{L}^{-1}$, the adsorption capacity of R-BC700 to SMX was $12.40 \mathrm{mg} \cdot \mathrm{g}^{-1}$, which might be ascribed to the significant increase of functional groups on the surface of biochar, especially related to the content of $\mathrm{C}=\mathrm{C}$ and $\mathrm{C}=\mathrm{O}$, as shown in Figure 2. In contrast, with the calcination temperature increase from $700{ }^{\circ} \mathrm{C}$ to $800{ }^{\circ} \mathrm{C}$, the content of oxygen functional groups did not change significantly, as seen in Figure 2e,f. The decrease of the adsorption capacity of R-BC800 might be ascribed to the collapse of the pore structure caused by the calcination at $800{ }^{\circ} \mathrm{C}$ [34]. Hence, the high-temperature reduction could affect the adsorption capacity of biochar via changing the species and content of functional groups, but the effect of reduction temperature on the adsorption capacity of biochar was limited. To further explore the adsorption mechanism of the modified biochar to SMX, the Langmuir and Freundlich models were fitted to the above isotherms, shown in Table 3. Compared with the Langmuir model, the adsorption curves of SMX by BC, $\mathrm{O}-\mathrm{BC}, \mathrm{R}-\mathrm{BC} 600$ and R-BC700 were more in line with the Freundlich model, indicative of a multi-layer adsorption process. Additionally, the maximum adsorption capacities of $\mathrm{O}-\mathrm{BC}$ and R-BC700 for SMX were $4.91 \mathrm{mg} \cdot \mathrm{g}^{-1}$ and $14.66 \mathrm{mg} \cdot \mathrm{g}^{-1}$, respectively, which were 31 and 92 times the adsorption capacity of SMX by BC $\left(0.16 \mathrm{mg} \cdot \mathrm{g}^{-1}\right)$, indicating that the functional groups played an important role in the adsorption capacity of biochar. R-BC700 
also showed higher adsorption capacity for SMX $\left(14.66 \mathrm{mg} \cdot \mathrm{g}^{-1}\right)$ than the biochars derived from giant reed, rice straw, wheat straw and pine sawdust. However, the adsorption capacity of R-BC700 for SMX was lower than that of activated biochars from alfalfa, wood and bamboo (90.00-212.87 $\mathrm{mg} \mathrm{g}^{-1}$ ) (Table 4).
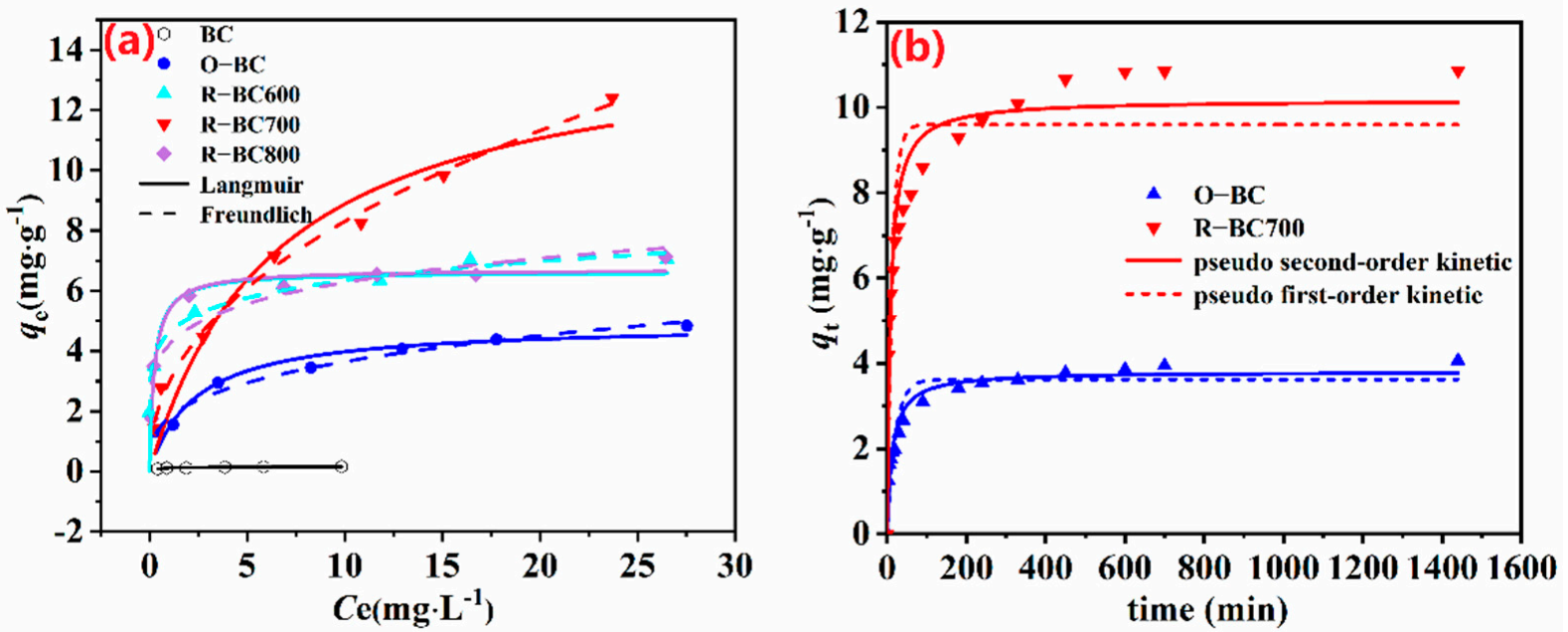

Figure 4. (a) Adsorption isotherms and (b) adsorption kinetics of SMX on biochars. (Dosage of adsorbent $=0.5 \mathrm{~g} \cdot \mathrm{L}^{-1}, \mathrm{SMX}$ concentration in adsorption isotherms $=0.5-30 \mathrm{mg} \cdot \mathrm{L}^{-1}, \mathrm{SMX}$ concentration in adsorption kinetics $=15 \mathrm{mg} \cdot \mathrm{L}^{-1}$, shaking speed $=180 \mathrm{rpm} ; \mathrm{t}=24 \mathrm{~h} ; \mathrm{T}=25^{\circ} \mathrm{C}$, initial $\mathrm{pH}=5.3$ ).

Table 3. Parameters of SMX adsorption isotherms on biochars with different modifications.

\begin{tabular}{|c|c|c|c|c|c|c|}
\hline \multirow[b]{2}{*}{ Biochars } & \multicolumn{3}{|c|}{ Langmuir } & \multicolumn{3}{|c|}{ Freundlich } \\
\hline & $\underset{\left(\mathrm{mg} \cdot \mathrm{g}^{-1}\right)}{q_{\max }}$ & $\begin{array}{c}K_{\mathrm{L}} \\
\left(\mathrm{L} \cdot \mathrm{mg}^{-1}\right)\end{array}$ & $R^{2}$ & $K_{\mathrm{F}}\left(\mathrm{L} \cdot \mathrm{g}^{-1}\right)$ & $\mathbf{n}$ & $R^{2}$ \\
\hline $\mathrm{BC}$ & 0.16 & 2.435 & 0.88 & 0.109 & 0.187 & 0.92 \\
\hline $\mathrm{O}-\mathrm{BC}$ & 4.91 & 0.424 & 0.93 & 1.800 & 0.307 & 0.98 \\
\hline R-BC600 & 6.64 & 4.235 & 0.78 & 4.612 & 0.138 & 0.99 \\
\hline R-BC700 & 14.66 & 0.153 & 0.95 & 2.969 & 0.447 & 0.99 \\
\hline R-BC800 & 6.71 & 3.951 & 0.97 & 4.220 & 0.172 & 0.88 \\
\hline
\end{tabular}

Table 4. Comparison of adsorption performance of various biochar adsorbents for sulfamethoxazole.

\begin{tabular}{|c|c|c|c|c|c|c|}
\hline \multirow[b]{2}{*}{ Adsorbents } & \multirow[b]{2}{*}{$q_{\max }\left(\mathrm{mg} \cdot \mathrm{g}^{-1}\right)$} & \multirow[b]{2}{*}{$\begin{array}{l}\text { Equilibrium } \\
\text { Time (min) }\end{array}$} & \multicolumn{3}{|c|}{ Conditions } & \multirow[b]{2}{*}{ References } \\
\hline & & & $\begin{array}{c}C_{0} \\
\left(\mathrm{mg} \cdot \mathrm{L}^{-1}\right)\end{array}$ & $\mathrm{pH}$ & $\begin{array}{c}\text { Adsorbent } \\
\text { Dosage }\left(g \cdot L^{-1}\right)\end{array}$ & \\
\hline Giant reed BC $\left(300^{\circ} \mathrm{C}\right)$ & 4.99 & \multirow{2}{*}{ Not mentioned } & \multirow{2}{*}{-} & \multirow{2}{*}{-} & \multirow{2}{*}{-} & \multirow{2}{*}[35]{} \\
\hline Giant reed $\mathrm{BC}\left(600^{\circ} \mathrm{C}\right)$ & 1.93 & & & & & \\
\hline Rice straw $\mathrm{BC}\left(300^{\circ} \mathrm{C}\right)$ & 4.21 & \multirow{2}{*}{ Not mentioned } & \multirow{2}{*}{-} & \multirow{2}{*}{-} & \multirow{2}{*}{-} & \multirow{2}{*}[36]{} \\
\hline $\begin{array}{c}\text { Wheat straw BC } \\
\left(300^{\circ} \mathrm{C}\right)\end{array}$ & 6.75 & & & & & \\
\hline Pine Sawdust BC & 13.80 & 30 & 20.5 & 4.0 & 2.0 & [37] \\
\hline Alfalfa-derived biochar & 90.00 & 180 & 100 & 5.0 & 0.1 & [38] \\
\hline $\begin{array}{l}\text { Wood-derived biochar } \\
\text { (boric acid-activated) }\end{array}$ & 212.87 & 240 & 50 & 5.0 & 0.5 & [39] \\
\hline $\begin{array}{c}\mathrm{CuZnFe}{ }_{2} \mathrm{O}_{4}-\mathrm{Bamboo} \\
\mathrm{BC}\end{array}$ & 212.87 & 30 & 20 & 7.0 & 0.2 & [40] \\
\hline R-BC700 & 14.66 & 20 & 15 & 5.3 & 0.5 & This work \\
\hline
\end{tabular}

Based on the characterization results, a correlational relationship between the adsorption distribution coefficient $\left(K_{\mathrm{d}}, K_{\mathrm{d}}\left(\mathrm{L} \cdot \mathrm{kg}^{-1}\right)=q_{\mathrm{e}} / C_{\mathrm{e}}\right)$ of biochars for SMX and their surface 
oxygen characteristics, are presented in Figure 5. The oxygen content of biochars presented a poor linear relationship with the $K_{\mathrm{d}}$ of biochars, with an $R^{2}$ of 0.3109 (Figure $5 \mathrm{a}$ ). Inversely, the species of oxygen functional groups $(\mathrm{C}=\mathrm{O}$ and $\mathrm{C}-\mathrm{O})$ showed a good correlation with the adsorption capacity of biochars (Figure $5 b, c$ ). The content of $\mathrm{C}=\mathrm{O}$ showed a significant positive correlation with the $K_{\mathrm{d}}$ of biochars, with an $R^{2} 0.9556$, while the content of C-O presented a negative correlation with the $K_{\mathrm{d}}$ of biochars, with an $R^{2} 0.7448$. The results confirmed the crucial role of surface oxygen functional groups in the adsorption capacity of biochars [15].
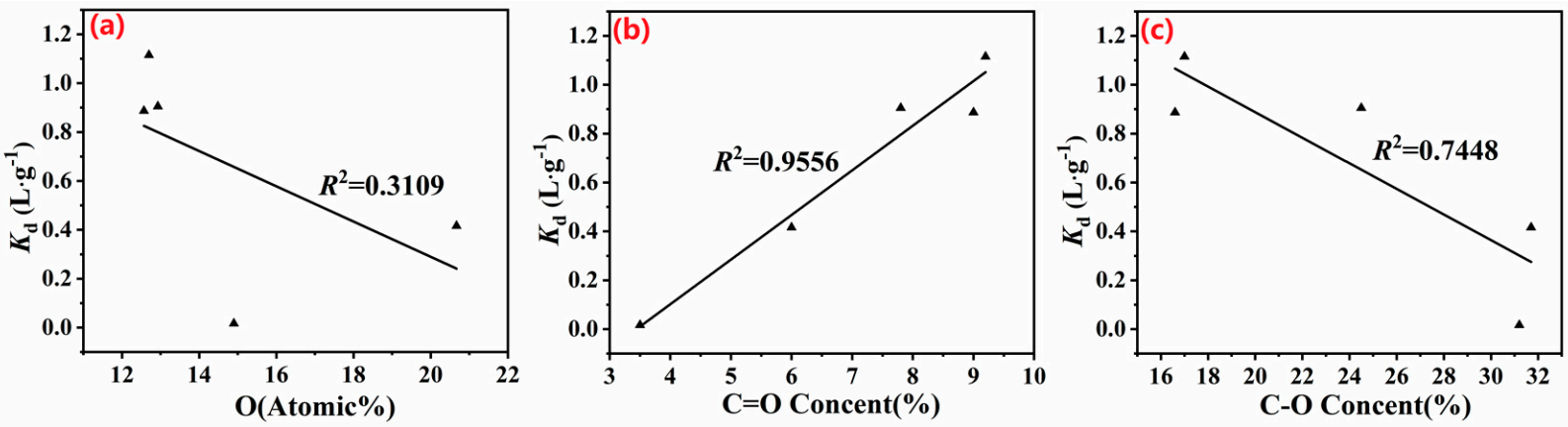

Figure 5. Correlations between $K_{\mathrm{d}}$ at $\mathrm{SMX}$ concentrations $10 \mathrm{mg} \cdot \mathrm{L}^{-1}$ and the (a) $\mathrm{O}$ content, (b) $\mathrm{C}=\mathrm{O}$ content and (c) $\mathrm{C}-\mathrm{O}$ content of biochars.

The adsorption kinetics of O-BC and R-BC700 on SMX are shown in Figure 4b. SMX was rapidly removed within $20 \mathrm{~min}$, and then the adsorption equilibrium was gradually reached. The adsorption equilibrium time of R-BC700 was shorter than other reported biochars in Table 4. This was due to the adsorbent providing abundant adsorption sites for SMX in the initial stage of adsorption. When the adsorption sites were occupied, the adsorption capacity tended to be saturated, with a reduced adsorption rate. To further study the adsorption behavior of the adsorbents, the pseudo-first-order and pseudo-secondorder kinetic models were used to fit the adsorption curves, and the fitting parameters are shown in Table 5. Compared with the pseudo-first-order model, the fitting results of the pseudo-second-order kinetic models of O-BC and R-BC700, had an $R^{2}$ of 0.95 and 0.93, respectively, which could well describe the adsorption process of SMX. The adsorption kinetics indicated that chemical adsorption was dominant in the adsorption process.

Table 5. Parameters of SMX adsorption kinetics on biochars with different modifications.

\begin{tabular}{|c|c|c|c|c|c|c|}
\hline \multirow[b]{2}{*}{ Biochars } & \multicolumn{3}{|c|}{ Pseudo-First-Order Kinetics } & \multicolumn{3}{|c|}{ Pseudo-Second-Order Kinetics } \\
\hline & $\begin{array}{c}q_{\mathrm{e}} \\
\left(\mathrm{mg} \cdot \mathrm{g}^{-1}\right)\end{array}$ & $\begin{array}{c}K_{1} \\
\left(\min ^{-1}\right)\end{array}$ & $R^{2}$ & $\begin{array}{c}q_{\mathrm{e}} \\
\left(\mathrm{mg} \cdot \mathrm{g}^{-1}\right)\end{array}$ & $\begin{array}{c}K_{2} \\
\left(\mathrm{~g} \cdot(\mathrm{mg} \cdot \mathrm{min})^{-1}\right)\end{array}$ & $R^{2}$ \\
\hline O-BC & 3.62 & 0.048 & 0.88 & 3.81 & 0.020 & 0.95 \\
\hline R-BC700 & 9.60 & 0.040 & 0.83 & 10.17 & 0.012 & 0.93 \\
\hline
\end{tabular}

Additionally, the adsorption rate constant $\left(k_{2}\right)$ of R-BC700 was $0.012 \mathrm{~g} \cdot(\mathrm{mg} \cdot \mathrm{min})^{-1}$, faster than that of $\mathrm{O}-\mathrm{BC}\left(0.020 \mathrm{~g} \cdot(\mathrm{mg} \cdot \mathrm{min})^{-1}\right)$, indicating that SMX could be quickly adsorbed on R-BC700, which might be ascribed to the fact that the removal of functional groups on the surface of R-BC700, weakened the steric hindrance effect, making SMX more accessible to the adsorption site.

\subsection{The Effect of Coexisting Interferents on SMX Adsorption}

The solution $\mathrm{pH}$ is an important factor for the adsorption of SMX. SMX contains two acid dissociation constants, namely, $p \mathrm{Ka}_{1}$ (about 1.7) and $p \mathrm{Ka}_{2}$ (about 5.6) [41], presenting different molecular states under different $\mathrm{pH}$ conditions (shown in Figure 6a). As shown in Figure 6c, the surface potentials of R-BC700 and BC decreased with the increase of 
solution, likely due to the dissociation of $\mathrm{C}-\mathrm{OH}$ groups [42]. The isoelectric point (IEP) of R-BC700 was about 1.5, indicative of a positively charged $\mathrm{R}-\mathrm{BC} 700$ at $\mathrm{pH}<1.5$ and a negatively charged R-BC700 at $\mathrm{pH}>1.5$. The IEP of R-BC700 was higher than that of BC $(<1.5)$, possibly due to the removal of partial polar oxygenated surface groups under the calcination process. Hence, the $\mathrm{pH}$ of the solution could affect both the existence of SMX and the surface charge of the biochar, further affecting the adsorption of SMX. The effect of the initial $\mathrm{pH}$ on the adsorption of R-BC700 to SMX, is shown in Figure 6b. When the $\mathrm{pH}$ increased from 3 to 4 , the adsorption capacity of R-BC700 for SMX increased from $12.99 \mathrm{mg} \cdot \mathrm{g}^{-1}$ to $13.78 \mathrm{mg} \cdot \mathrm{g}^{-1}$. When the $\mathrm{pH}$ further increased from 4 to 11 , the adsorption capacity of R-BC700 to SMX significantly decreased from $13.78 \mathrm{mg} \cdot \mathrm{g}^{-1}$ to $3.49 \mathrm{mg} \cdot \mathrm{g}^{-1}$, indicating that $\mathrm{R}-\mathrm{BC} 700$ presented an excellent adsorption capacity at $\mathrm{pH} 4$. At $\mathrm{pH} 4$, SMX was almost in a hydrophobic neutral state, resulting in the adsorption between R$\mathrm{BC} 700$ and $\mathrm{SMX}{ }^{0}$, mainly through hydrophobic interaction. When at $\mathrm{pH}>4, \mathrm{SMX}^{-}$and $\mathrm{R}-\mathrm{BC} 700$ showed electrostatic repulsion, resulting in a decrease of the adsorption capacity of R-BC700. Although there was electrostatic repulsion, R-BC700 still had an adsorption capacity for SMX, indicative of the presence of other adsorption mechanisms, such as pore filling, hydrogen bonding and surface complexation [43].
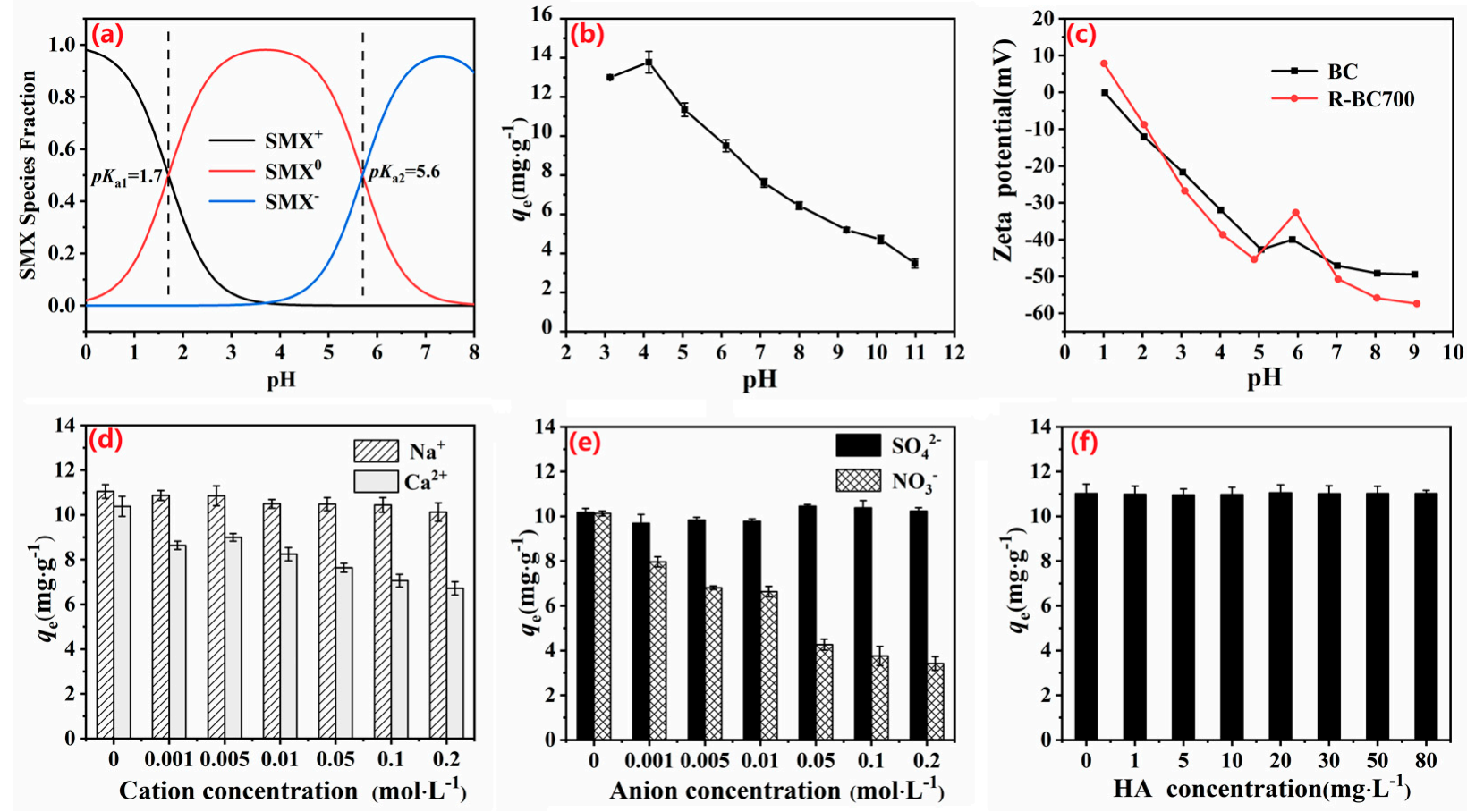

Figure 6. (a) Species distribution diagram for SMX; (b) effects of initial $\mathrm{pH}$ on adsorption of SMX on $\mathrm{R}$-BC700 (dosage of adsorbent $=0.5 \mathrm{~g} \cdot \mathrm{L}^{-1}, \mathrm{SMX}$ concentration $=15 \mathrm{mg} \cdot \mathrm{L}^{-1}$, shaking speed $=180 \mathrm{rpm}$; $\mathrm{t}=24 \mathrm{~h} ; \mathrm{T}=25^{\circ} \mathrm{C}$, initial $\mathrm{pH}=3-11$ ); (c) zeta potential of BC and R-BC700 (dosage of adsorbent = $0.5 \mathrm{~g} \cdot \mathrm{L}^{-1}$, initial $\left.\mathrm{pH}=1-10\right)$; effects of $(\mathbf{d})$ cations, (e) anions and (f) HA on the adsorption of SMX on R-BC700. (Dosage of adsorbent $=0.5 \mathrm{~g} \cdot \mathrm{L}^{-1}, \mathrm{SMX}$ concentration $=15 \mathrm{mg} \cdot \mathrm{L}^{-1}$, shaking speed = $180 \mathrm{rpm} ; \mathrm{t}=24 \mathrm{~h} ; \mathrm{T}=25^{\circ} \mathrm{C}$, initial $\mathrm{pH}=5.3$ ).

Considering the complexity of the environmental matrix, the effects of ion species $\left(\mathrm{Na}^{+}, \mathrm{Ca}^{2+}, \mathrm{NO}_{3}{ }^{-}, \mathrm{SO}_{4}{ }^{2-}\right)$, ionic strengths and humic acid (HA) on the removal of SMX on biochar, were further investigated. As shown in Figure 6d, the adsorption capacity of $\mathrm{R}$-BC700 for SMX slightly decreased with an increase in the concentration of $\mathrm{Na}^{+}$from 0.001 to $0.2 \mathrm{~mol} \cdot \mathrm{L}^{-1}$, which might be due to the adsorption of $\mathrm{Na}^{+}$on the negatively charged surface, thus forming competitive adsorption with SMX. Whereas, $\mathrm{Ca}^{2+}$ presented a significant inhibitory effect on the adsorption of SMX, indicative of stronger competitive adsorption between $\mathrm{Ca}^{2+}$ with SMX [44]. Figure 6e shows the effect of $\mathrm{NO}_{3}{ }^{-}$and $\mathrm{SO}_{4}{ }^{2-}$ on 
the adsorption of SMX. With the increase of $\mathrm{NO}_{3}{ }^{-}$from 0.001 to $0.2 \mathrm{~mol} \cdot \mathrm{L}^{-1}$, the adsorption capacity of R-BC700 to SMX decreased from $10.13 \mathrm{mg} \cdot \mathrm{g}^{-1}$ to $3.42 \mathrm{mg} \cdot \mathrm{g}^{-1}$. Inversely, the concentration of $\mathrm{SO}_{4}{ }^{2-}$ had a slight inhibitory effect on the adsorption of SMX. This result indicated that the inhibitory effect of anions might be related to the type of anion, rather than the degree of charge [45].

HA is rich in phenolic hydroxyl and carboxyl groups, playing a vital role in the removal and transformation of pollutants. Hence, the effect of HA on the adsorption of SMX was further studied, and the result is shown in Figure 6f. Studies have reported that HA could adsorb on carbon materials via $\pi-\pi$ interactions, hydrogen bonds, hole filling and electrostatic interactions, generating a competition mechanism with the adsorption of aromatic compounds [46]. In this study, the concentration of HA showed a negligible effect on the adsorption capacity of SMX on R-BC700 with a concentration increase of HA from 0 to $80 \mathrm{mg} \cdot \mathrm{L}^{-1}$, ascribed to the steric hindrance of HA [47]. Additionally, HA-containing acidic groups (e.g., carboxyl and phenolic hydroxyl groups) would dissociate, leading to the negatively charged HA at experimental conditions [48]. Hence, HA and R-BC700 demonstrated electrostatic repulsion, weakening the competition for active adsorption sites.

\section{Conclusions}

In this study, oxidation- and reduction-modified biochars were prepared and used as adsorbents to investigate the adsorption mechanism of SMX in water. The adsorption isotherm results showed that both oxidations modified biochar $(\mathrm{O}-\mathrm{BC})$ and the reductionmodified biochar (R-BCX) presented a significant improvement in the adsorption capacity for SMX; the adsorption capacity of biochar presented the adsorption order of R-BC700 $\left(14.66 \mathrm{mg} \cdot \mathrm{g}^{-1}\right)>\mathrm{O}-\mathrm{BC}\left(4.91 \mathrm{mg} \cdot \mathrm{g}^{-1}\right)>\mathrm{BC}\left(0.16 \mathrm{mg} \cdot \mathrm{g}^{-1}\right)$. The effects of co-existing environmental interferents such as $\mathrm{pH}$, ion species, ionic strength, and HA concentration on the adsorption of R-BC700 to SMX were investigated. By combining the characterization results of the composition and chemical structure of biochar before and after modification, it was shown that the functional groups had a significant impact on the adsorption capacity of biochar. The $\mathrm{C}=\mathrm{O}$ and $\mathrm{C}=\mathrm{C}$ functional groups, resulting in a $\pi-\pi$ interaction, were in favor of the adsorption of SMX, while the C-O functional group was not conducive to the adsorption of SMX, due to the steric hindrance and negative surface charge. Additionally, the hydrophobic effect of the biochar was also one of the adsorption mechanisms. This study provides an important theoretical basis for revealing the adsorption mechanism of organic matter on carbon materials. Furthermore, the practical application of R-BC700 should be performed and the specific contribution rate of each mechanism of organic adsorption on the adsorbent, is worth studying in the future.

Author Contributions: Conceptualization, J.H. and J.Y.; methodology, J.H..; validation, W.L., X.H. and J.Y.; formal analysis, J.H.; investigation, J.H.; resources, J.Y.; data curation, J.Y.; writing-original draft preparation, J.Y. and J.H.; writing-review and editing, J.H.; visualization, X.H.; supervision, W.L.; project administration, W.L.; funding acquisition, J.H. and X.L. All authors have read and agreed to the published version of the manuscript.

Funding: This research was funded by the Key research and development projects of Anhui Province, grant number 202004a06020007 and the Natural Science Foundation of Anhui Province, grant number 2008085QB72 from Science and Technology Department of Anhui Province.

Institutional Review Board Statement: Not applicable.

Informed Consent Statement: Not applicable.

Data Availability Statement: Not applicable.

Conflicts of Interest: The authors declare no conflict of interest. 


\section{References}

1. Nam, S.W.; Jung, C.; Li, H.; Yu, M.; Flora, J.R.V.; Boateng, L.K.; Her, N.; Zoh, K.-D.; Yoon, Y. Adsorption characteristics of diclofenac and sulfamethoxazole to graphene oxide in aqueous solution. Chemosphere 2015, 136, 20-26. [CrossRef] [PubMed]

2. Wei, J.; Liu, Y.T.; Zhu, Y.H.; Yu, H.; Peng, Y.Z. Adsorption and co-adsorption of tetracycline and doxycycline by one-step synthesized iron loaded sludge biochar. Chemosphere 2019, 236, 1224254. [CrossRef] [PubMed]

3. Liu, X.H.; Zhang, G.D.; Liu, Y.; Lu, S.Y.; Qin, P.; Guo, X.C.; Bi, B.; Wang, L.; Xi, B.D.; Wu, F.C.; et al. Occurrence and fate of antibiotics and antibiotic resistance genes in typical urban water of Beijing. China Environ. Pollut. 2019, 246, 163-173. [CrossRef] [PubMed]

4. Rahele, R.; Hassan, B. A comparative adsorption study of sulfamethoxazole onto graphene and graphene oxide nanosheets through equilibrium, kinetic and thermodynamic modeling. Process Saf. Environ. 2016, 102, 20-29.

5. Guan, Y.D.; Wang, B.; Gao, Y.; Liu, W.; Zhao, X.; Huang, X.; Yu, J.H. Occurrence and fate of antibiotics in the aqueous environment and their removal by constructed wetlands in China: A review. Pedosphere 2017, 27, 42-51. [CrossRef]

6. Wang, T.; Ai, S.; Zhou, Y.; Luo, Z.; Dai, C.; Yang, Y.; Zhang, J.C. Adsorption of agricultural wastewater contaminated with antibiotics, pesticides and toxic metals by functionalized magnetic nanoparticles. J. Environ. Chem. Eng. 2018, 6, 6468-6478. [CrossRef]

7. Mandu, I.; Gao, B.; Zimmerman, A.; Zhang, M.; Hao, C. Synthesis, characterization, and dye sorption ability of carbon nanotubebiochar nanocomposites. Chem. Eng. J. 2014, 236, 39-46.

8. Jiang, S.F.; Sheng, G.P.; Jiang, H. Advances in the characterization methods of biomass pyrolysis products. J. ACS Sustain. Chem. Eng. 2019, 7, 12639-12655. [CrossRef]

9. Peiris, C.; Gunatilake, S.R.; Mlsna, T.E.; Mohan, D.; Vithanage, M. Biochar based removal of antibiotic sulfonamides and tetracyclines in aquatic environments: A critical review. J. Bioresour. Technol. 2017, 46, 150-159. [CrossRef]

10. Greiner, B.G.; Shimabuku, K.K.; Summers, R.S. Influence of biochar thermal regeneration on sulfamethoxazole and dissolved organic matter adsorption. Environ. Sci. Water Res. Technol. 2018, 4, 169-174. [CrossRef]

11. Teixidó, M.; Pignatello, J.J.; Beltrán, J.L.; Granados, M.; Peccia, J. Speciation of the Ionizable Antibiotic Sulfamethazine on Black Carbon (Biochar). Environ. Sci. Technol. 2011, 45, 10020-10027. [CrossRef] [PubMed]

12. Wu, M.; Pan, B.; Zhang, D.; Xiao, D.; Li, H.; Wang, C.; Ning, P. The sorption of organic contaminants on biochars derived from sediments with high organic carbon content. Chemosphere 2013, 90, 782-788. [CrossRef] [PubMed]

13. Suliman, W.; Harsh, J.B.; Abu-Lail, N.I.; Fortuna, A.; Dallmeyer, I.; Garcia-Perez, M. Modification of biochar surface by air oxidation: Role of pyrolysis temperature. Biomass Bioenergy 2016, 85, 1-11. [CrossRef]

14. Chen, D.Y.; Yu, X.Z.; Song, C.; Pang, X.L.; Huang, J.; Li, Y.J. Effect of pyrolysis temperature on the chemical oxidation stability of bamboo biochar. Bioresour. Technol. 2016, 218, 1303-1306. [CrossRef] [PubMed]

15. Fan, Q.Y.; Sun, J.X.; Chu, L.; Cui, L.Q.; Quan, G.X.; Yan, J.L.; Hussain, Q.; Lqbal, M. Effects of chemical oxidation on surface oxygen-containing functional groups and adsorption behavior of biochar. Chemosphere 2018, 207, 33-40. [CrossRef]

16. Yang, J.-C.E.; Zhu, M.-P.; Dionysiou, D.D.; Yuan, B.L.; Fu, M.-L. Interplay of bicarbonate and the oxygen-containing groups of carbon nanotubes dominated the metal-free activation of peroxymonosulfate. Chem. Eng. J. 2022, 430, 133102. [CrossRef]

17. Ntzoufra, P.; Vakros, J.; Frontistis, Z.; Tsatsos, S.; Kyriakou, G.; Kennou, S.; Manariotis, I.D.; Mantzavinos, D. Effect of sodium persulfate treatment on the physicochemical properties and catalytic activity of biochar prepared from spent malt rootlets. $J$. Environ. Chem. Eng. 2021, 9, 105071. [CrossRef]

18. Hu, P.D.; Long, M.C. Cobalt-catalyzed sulfate radical-based advanced oxidation:A review on heterogeneous catalysts and applications. Appl. Catal. B Environ. 2016, 181, 103-117. [CrossRef]

19. Figueiredo, J.L.; Pereira, M.F.R.; Freitas, M.M.A.; Orfao, J.J.M. Modification of the surface chemistry of activated carbons. Carbon 1999, 37, 1379-1389. [CrossRef]

20. Wang, H.; Xia, W.; Lu, P. Study on adsorption characteristics of biochar on heavy metals in soil. Korean J. Chem. Eng. 2017, 34, 1867-1873. [CrossRef]

21. Tao, Q.; Chen, Y.X.; Zhao, J.W.; Li, B.; Li, Y.H.; Tao, S.Y.; Li, M.; Li, Q.Q.; Xu, Q.; Li, Y.B.; et al. Enhanced Cd removal from aqueous solution by biologically modified biochar derived from digestion residue of corn straw silage. Sci. Total Environ. 2019, 674, 213-222. [CrossRef]

22. Qian, L.B.; Zhang, W.Y.; Yan, J.C.; Han, L.; Gao, W.G.; Liu, R.Q.; Chen, M.F. Effective removal of heavy metal by biochar colloids under different pyrolysis temperatures. Bioresour. Technol. 2016, 206, 217-224. [CrossRef] [PubMed]

23. Xu, J.; Liu, J.W.; Zhang, X.; Xu, K.; He, L.M.; Wang, Y.; Su, S.; Hu, S.; Xiang, J. Raman spectroscopy of biochar from the pyrolysis of three typical Chinese biomasses: A novel method for rapidly evaluating the biochar property. Energy 2020, 202, 117644. [CrossRef]

24. Ouyang, D.; Chen, Y.; Yan, J.C.; Qian, L.B.; Han, L.; Chen, M.F. Activation mechanism of peroxymonosulfate by biochar for catalytic degradation of 1,4-dioxane: Important role of biochar defect structures. Chem. Eng. J. 2019, 370, 614-624. [CrossRef]

25. Huang, Z.; Wu, P.; Gong, B.; Lu, Y.; Zhu, N.; Hu, Z. Preservation of Fe complexes into layered double hydroxides improves the efficiency and the chemical stability of Fe complexes used as heterogeneous photo-Fenton catalysts. Appl. Surf. Sci. 2013, 286, 371-378. [CrossRef]

26. Fan, S.S.; Tang, J.; Wang, Y.; Li, H.; Zhang, H.; Tang, J.; Wang, Z.; Li, X. Biochar prepared from co-pyrolysis of municipal sewage sludge and tea waste for the adsorption of methylene blue from aqueous solutions: Kinetics, isotherm, thermodynamic and mechanism. J. Mol. Liq. 2016, 220, 432-441. [CrossRef] 
27. Pal, D.; Maiti, S.K. Abatement of cadmium (Cd) contamination in sediment using tea waste biochar through meso-microcosm study. J. Clean. Prod. 2019, 212, 986-996. [CrossRef]

28. Huang, H.; Niu, Z.; Shi, R.R.; Tang, J.C.; Lv, L.; Wang, J.; Fan, Y.M. Thermal oxidation activation of hydrochar for tetracycline adsorption: The role of oxygen concentration and temperature. Bioresour. Technol. 2020, 306, 123096. [CrossRef]

29. Kundu, S.; Wang, Y.M.; Xia, W.; Muhler, M. Thermal Stability and Reducibility of Oxygen-Containing Functional Groups on Multiwalled Carbon Nanotube Surfaces: A Quantitative High-Resolution XPS and TPD/ TPR Study. J. Phys. Chem. C 2008, 112, 16869-16878. [CrossRef]

30. Wang, Y.F.; Gao, Z.X.; Shang, Y.X.; Qi, Z.Y.; Zhao, W.; Peng, Y.Z. Proportional modulation of zinc-based MOF/carbon nanotube hybrids for simultaneous removal of phosphate and emerging organic contaminants with high efficiency. Chem. Eng. J. 2021, 417, 128063. [CrossRef]

31. Qi, C.L.; Ma, X.L.; Ning, G.Q.; Song, X.Y.; Chen, B.; Lan, X.Y.; Li, Y.F.; Zhang, X.; Gao, J.S. Aqueous slurry of S-doped carbon nanotubes as conductive additive for lithium ion batteries. Carbon 2015, 92, 245-253. [CrossRef]

32. Zhang, X.P.; Zhang, H.; Song, X.X.; Han, X.K.; Bao, J.J.; Zhang, N.; He, G.H. $\mathrm{Co}_{3} \mathrm{O}_{4}$-based catalysts derived from natural wood with hierarchical structure for elemental mercury oxidation. J. Energy. Inst. 2021, 94, 285-293. [CrossRef]

33. Cho, H.H.; Smith, B.A.; Wnuk, J.D.; Fairbrother, D.H.; Ball, W.P. Influence of surface oxides on the adsorption of naphthalene onto multiwalled carbon nanotubes. Environ. Sci. Technol. 2008, 42, 2899-2905. [CrossRef] [PubMed]

34. Xu, Z.B.; He, M.J.; Xu, X.Y.; Cao, X.D.; Tsang, D.C.W. Impacts of different activation processes on the carbon stability of biochar for oxidation resistance. Bioresour. Technol. 2021, 338, 125555. [CrossRef] [PubMed]

35. Zheng, H.; Wang, Z.; Zhao, J.; Herbert, S.; Xing, B. Sorption of antibiotic sulfamethoxazole varies with biochars produced at different temperatures. Environ. Pollut. 2013, 181, 60-67. [CrossRef] [PubMed]

36. Sun, B.; Lian, F.; Bao, Q.; Liu, Z.; Song, Z.; Zhu, L. Impact of low molecular weight organic acids (LMWOAs) on biochar micropores and sorption properties for sulfamethoxazole. Environ. Pollut. 2016, 214, 142-148. [CrossRef] [PubMed]

37. Reguyal, F.; Sarmah, A.K.; Gao, W. Synthesis of magnetic biochar from pine sawdust via oxidative hydrolysis of $\mathrm{FeCl}_{2}$ for the removal sulfamethoxazole from aqueous solution. J. Hazard. Mater. 2017, 321, 868-878. [CrossRef]

38. Choi, Y.K.; Kan, E. Effects of pyrolysis temperature on the physicochemical properties of alfalfa-derived biochar for the adsorption of bisphenol A and sulfamethoxazole in water. Chemosphere 2019, 218, 741-748. [CrossRef]

39. Zhang, X.; Guang, D.D.; Zhang, J.J.; Lei, X.B.; Lian, Q.Y.; Holmes, W.E.; Zappi, M.e.; Yao, H. Insight into the activation mechanisms of biochar by boric acid and its application for the removal of sulfamethoxazole. J. Hazard. Mater. 2022, 424, 127333. [CrossRef]

40. Heo, J.; Yoon, Y.; Lee, G.; Kim, Y.; Han, J.; Park, C.M. Enhanced adsorption of bisphenol A and sulfamethoxazole by a novel magnetic $\mathrm{CuZnFe}{ }_{2} \mathrm{O}_{4}$-biochar composite. Bioresour. Technol. 2019, 281, 179-187. [CrossRef]

41. Prasannamedha, G.; Kumar, P.S.; Mehala, R.; Sharumitha, T.G.; Surendhar, D. Enhanced adsorptive removal of sulfamethoxazole from water using biochar derived from hydrothermal carbonization of sugarcane bagasse. J. Hazard. Mater. 2021, $407,124825$. [CrossRef] [PubMed]

42. Qi, X.H.; Li, L.Y.; Wang, Y.; Liu, N.; Smith, R.L., Jr. Removal of hydrophilic ionic liquids from aqueous solutions by adsorption onto high surface area oxygenated carbonaceous material. Chem. Eng. J. 2014, 256, 407-414. [CrossRef]

43. Li, Q.; Yu, W.; Guo, L.W.; Wang, Y.H.; Zhao, S.Y.; Zhou, L.; Jiang, X.H. Sorption of sulfamethoxazole on inorganic acid solution etched biochar derived from Alfalfa. Materials 2021, 14, 1033. [CrossRef]

44. Ji, L.L.; Chen, W.; Zheng, S.R.; Xu, Z.Y.; Zhu, D.Q. Adsorption of sulfonamide antibiotics to multiwalled carbon nanotubes. Langmuir 2009, 25, 11608-11613. [CrossRef] [PubMed]

45. Lv, M.; Li, D.Y.; Zhang, Z.H.; Logan, B.E.; Liu, G.H.; Sun, M.C.; Dai, C.C.; Feng, Y.J. Unveiling the correlation of Fe $\mathrm{O}_{4}$ fractions upon the adsorption behavior of sulfamethoxazole on magnetic activated carbon. Sci. Total Environ. 2021, 757, 143717. [CrossRef] [PubMed]

46. Daifullah, A.; Girgis, B.S.; Gad, H. A study of the factors affecting the removal of humic acid by activated carbon prepared from biomass material. Colloid. Surf. A 2004, 235, 1-10. [CrossRef]

47. Yang, D.X.; Li, J.; Luo, L.; Deng, R.Y.; He, Q.; Chen, Y. Exceptional levofloxacin removal using biochar-derived porous carbon sheets: Mechanisms and density-functional-theory calculation. Chem. Eng. J. 2020, 387, 124103. [CrossRef]

48. Illés, E.; Tombácz, E. The role of variable surface charge and surface complexation in the adsorption of humic acid on magnetite. Colloid. Surf. A 2004, 230, 99-109. [CrossRef] 